\title{
PRACTICE OF CROSS BORDER COOPERATION IN CAPACITY BUILDING PROJECT: ENSURING SUSTAINABLE DEVELOPMENT
}

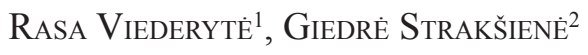 \\ Klaipèda University (Lithuania)
}

\begin{abstract}
The article presents the practice of Capacity Building project (CBP) activities underlining the sustainable development importance in the context of Cross Border Cooperation, which was implemented in Denmark, Germany, Poland, Sweden and Lithuania. The article is based on the analysis of statistical data and South Baltic Program documents adopted by the European Commission. The knowledge and experience of CBP formulated in this paper could be useful for future capacity building initiatives in the South Baltic region or in other territorial cooperation programmes. Article authors were official representatives of this project in Lithuania Region and actively participated during the Capacity Building project activities implementation process, took responsibilities during the interview and questionnaire givens collecting in Lithuania, were mentoring the Rent-of-Expert process and made individual consultations, organized trainings and workshops.

KEY WORDS: Cross Border Cooperation, Capacity Building project, South Baltic Programme.
\end{abstract}

JEL CODES: O19, O22, O31, O57.

\section{Introduction}

The 'EU Strategy for the Baltic Sea Region' is described in three documents: (1) a Communication from the European Commission to the Council and the European Parliament, (2) an associated Action Plan which complements the Communication, presented to the Council and European Parliament at the same time and (3) a Working Document of the European Commission's Services which presents the background, approach and content of the strategy.

The priority areas are organized into four thematic 'pillars' and one horizontal section. It is important to appreciate, however, that this is only for ease of analysis. In fact, every pillar relates to a wide range of policies and will have impacts on the other pillars: they are interlinked and interdependent. Each priority area starts with a presentation of the issue providing background information on the topic. Then, the hotspots (main problems) are indicated and the added value of the action for the Baltic Sea Region is presented.

The priority areas are implemented through detailed actions which are explained. Some actions are strategic for the Baltic Sea Region as they are designed to address specific and important issues for its regions, citizens and enterprises. Others are cooperative, meaning they are based on the benefits in improving cooperation on issues where Member States and stakeholders are ready to do so. In some cases, actions might

\footnotetext{
Rasa Viederytė - Klaipeda University, project Management Department, the head of project Management Department. Scientific interest: management of projects.

E-mail: rasa.viederyte@ku.lt

Tel.: +37046398 776

2 Giedre Strakšienė - Klaipėda University, project Management Department. Scientific interest: management of projects.

E-mail: giedre.straksiene@ku.lt

Tel.: +37046398 776
} 
require a change in the policy orientation or national legislation of the Member States in the Baltic Sea Region. In others, they require financing which could be provided by private or public funding (EU, national, regional or local funds). All actions should be understood without prejudice to the existing exclusive Community competences (Communication from the Commission to the European Parliament, the Council, the European Economic and Social Committee and the Committee of the Regions concerning the European Union Strategy for the Baltic Sea Region Action Plan (2009).

The period of 2007-2013 brings several major changes to the South Baltic Programmes dealing with the territorial co-operation in the European Union. Most importantly the territorial co-operation objective includes three main aspects:

- development of economic and social cross-border activities (cross-border cooperation);

- establishment and development of transnational co-operation, including bilateral co-operation between maritime regions;

- increasing the efficiency of regional policy through interregional promotion and cooperation, the networking and exchange of experiences between regional and local authorities (interregional cooperation).

The South Baltic Programme is developed right on this initiative. In formal terms it is the so called multilateral cross-border co-operation Programme created on the maritime border between the Southern Baltic Sea regions. In practical terms the South Baltic Programme is a completely new co-operation area where cross-border co-operation structures have not been developed to the full scale yet. The programme area, however, shows strong cross-border links developed through cooperation in Euroregion Baltic, Euroregion Pomerania, the South Baltic Four Corners Cooperation and many bilateral initiatives. These initiatives managed to contribute to stronger connection and economically beneficial development of neighbouring areas, and therefore may form a fundament for the programme actions.

Considering the new changes in the Programme was started the Capacity Building project, that aims were to attract better the main target group (newcomers, especially from local authorities and NGO's) to the South Baltic Programme and to strengthen their capacity to prepare and later to implement good projects within the Programme.

The project realised the afore-mentioned aims through three principal activity strands:

- National trainings - an introduction to international project development, addressed mainly to beginners;

- Cross-border workshops - addressed to beneficiaries with an identified project idea for a project within the South Baltic Programme;

- Rent-an-expert facility - individual advisory services on project development.

Problem. Various cross-border initiatives were provided within the South Baltic Programme, but there's no evaluation on the program applying abilities and knowledge, based for starting to participate in the Program. Capacity building project (CBP) was launched to help with the South Baltic Programme participation issues, by providing real help on how to start project planning process, how apply the proposal, where to look for partners, etc. It is also believed that the knowledge and experience of CBP formulated in this paper could be useful for future capacity building initiatives in the South Baltic region or in other territorial cooperation programmes. In addition, the findings of this paper could potentially be used to better tailor ETC programmes in the next funding periods. There's question how Capacity Building project ensure sustainable development at least among countries-participants.

Purpose of article: to disclose practice of Capacity Building project emphasizing the sustainable development in the context of Cross Border Cooperation.

The research objectives are: theoretically substantiate the concept of Capacity Building project in the South Baltic programme, empirical surveying barriers and support for project development and to compare results. 
The following methods were applied: analysis of scientific literature and documents, questionnaire-in written; interview-in-written, statistical analysis of data.

\section{The concept of Capacity Building project}

Capacity Building Project (CBP), realized within the South Baltic Programme, was launched to help potential beneficiaries of the Programme in the preparation and implementation of cross-border projects. The project arose from the analysis of results of the two first application rounds within the South Baltic Programme, which showed that there was a strong interest and demand for funding cross-border co-operation among local public authorities, publicly owned corporations, regional public authorities, universities and non-governmental organizations. However, there was a significant discrepancy between the number of applying institutions and the number of successfully applying institutions. Although many projects presented valuable ideas, their quality was not sufficient to receive funding. This proved that there was an apparent lack of knowledge and experience in cross-border projects' development among the Programme's potential beneficiaries. The Capacity Building Project aimed to bridge this gap through various trainings and tailored assistance and to facilitate development of joint project proposals of cross-border character.

The aim of the Capacity Building Project was to support participation in the South Baltic Programme, particularly among local authorities and NGOs who constitute the target group of the Project. Capacity Building was offering the following free-of-charge services:

1. Training on project development - trainings in national languages, introduced the participants to a variety of tools and methods used to identify, develop and manage projects; the participants learned how to generate project ideas, identify partners, plan and prepare projects, estimate costs etc;

2. Cross-border workshops - the workshops were addressed to beneficiaries who have already identified concrete ideas for development of projects within the SB Programme; participation in the workshops prepared beneficiaries for concrete cooperation in joint projects

3. Individual project consultations - potential beneficiaries could receive free-of-charge consultations on project development.

Beginners were given guidelines and tools necessary for project development during national trainings. More advanced beneficiaries took part in the cross-border workshops, were they received structured feedback on their ideas from a panel of experts. Many projects received support under the Rent-an-Expert service: they were supported in the development of their project idea by either an external expert or a mentor from the CBP team.

\subsection{Training sessions}

The CBP on 2010 started training sessions for potential programme beneficiaries. The goal of the training is was develop skills and knowledge of the potential programme beneficiaries which lead to their increased participation in the SBP. Trainings were held in national languages, in groups of 15 up to 25 people. The trainings were delivered by Action Learning method, i.e. participants were working with case studies and exercises to allow them to understand the process of project development. The participants learned how to generate project ideas, identify partners, plan and prepare projects, estimate costs etc. There were 3 one-day training sessions planned in all partner countries.

In September and October partners of the Capacity Building Project, with the help of Regional Contact Points, organized trainings for the beneficiaries of South Baltic Programme.

Fifteen training sessions were held in all Programme countries: 3 in Lithuania (Kretinga, Klaipeda and Taurage), 3 in Denmark (2 on Zealand and 1 in Ronne), 3 in Germany (in Rostock), 4 in Sweden (in Kalmar, Blekinge, Skane and Kronoberg). The participants included representatives of regional administration, municipalities, NGOs, museums and universities and various associations. The trainings were moderated by Capacity partners. 
The trainings concentrated on the development of international projects, with special focus on SBP. They were delivered by Action Learning method, i.e. participants worked with case studies and practical exercises that allowed them to understand the process of project development. The trainers introduced the participants to general skills on project development and management such as creating a Gannt chart or planning activities and basic knowledge about projects as such. The participants learnt about the specific features of South Baltic projects and equipped with this knowledge they stared working on own project ideas. They defined objectives and results and learnt how to frame them into South Baltic Programme. Some activities were devoted to the identification of project activities and outputs. Trainers explained also how to find partners and form partnership.

These training sessions were addressed to beginners, with little experience in international project development. Most of the material presented was in national languages, though texts from real applications were kept in English, in Sweden, in German, in Lithuanian and in Danish. A very practical and hands on material was produced by the Capacity Building Project and used during all trainings. Since many of our interviewees considered the application process as complicated, our training materials highlighted some important parts of the application form, to get rid of the perception of it being more complicated that it really is. Trainees were introduced to basic concepts of project development.

The national training conducted by the partners in the SBP CAPACITY project has been well received and evaluated by the participants. Project have trained about 270 persons in the entire region, out of which 88 in Sweden, 66 in Poland, 43 in Lithuania, 42 in Denmark, and 28 in Germany. Project administration group hoped that the basic project development skills will allow them to develop new projects and applications for future calls. The implementation of the national training package that was planned within CAPACITY means that this part has been completed.

\subsection{Workshops}

For those who have already got some project ideas, project conducted two cross-border workshops in Klaipeda (29 participants) and in Gdynia (43 participants). The two workshops were also received extremely well, and participants met new potential partners, learnt from each others' experiences and got professional advice from experts. All in all, they had a chance to get the feeling that developing projects in the South Baltic Programme is not so extremely difficult.

From October 21st - lunch - till October 22nd - lunch, 2011 the first Capacity Building Project crossborder workshop took place in Klaipeda, Lithuania. The workshop gathered 29 participants from all countries in the area of the South Baltic Programme; beneficiaries that wanted to have their project ideas assessed and discussed by a panel of experts and Partners from the Capacity Building project.

The work for the participants had started prior to the workshop itself. The beneficiaries had worked with their project ideas, presented them in writing and prepared 10 minutes presentation.

Most had used the template for structuring a project idea provided by the Capacity Building Project. All participants were eager to have their feedback. The experts pointed out both strengths and weaknesses with the presented projects, one by one and also made recommendations. It became obvious that many projects had similar weaknesses; some comments could be expressed more in general. Quite a few also needed to extend their partnership, and thanks to the fact that all participants had listened to all projects some projects got offers from other participants that knew organizations back home that probably would be interested to join. Contact details were exchanged.

Some projects did not fit into the South Baltic Project at all, mainly because they were more local, had no cross-border value. These projects were recommended other funding possibilities to start with, and later on extend, in many cases interesting scopes, to include a wider geographical area. To make a budget is not always easy. 


\subsection{Individual consultations}

If beneficiaries felt that trainings and workshops were not enough, they were taking individual project consultations. Capacity Building pool of experts consisted of 50 professional consultants who were ready to offer their knowledge and experience to help develop project idea into a good project application. The consultations were free of charge. All beneficiaries had to do was fill an on-line application form available on website www.sbpcapatity.org and submit before the deadline. Provided that application was approved, an expert was allocated to beneficiary to guide through the process of preparing the application.

If beneficiaries had some problematic question or uncertainty, before asking for full scale Rent-an-Expert service, beneficiaries were always welcome to ask Project Contact in them country for mentoring assistance.

\section{Analysis of barriers for Project development}

To achieve its objectives the CBP carried out an analysis aimed at identifying the obstacles and needs of support among the Programme's potential beneficiaries. The analysis was based on the results of questionnaires and interviews. It aimed to shed some light on the barriers that hamper a smooth development of projects and thematic areas the beneficiaries are most interested in.

The analysis was carried out in two steps. The first step was a standardized web-based or printed closedquestion questionnaire. The broad group of potential Programme beneficiaries were encouraged to fill-out the questionnaires in order to define specific reasons for a lack of their activity in the international programmes and SBP in particular. In total 220 questionnaires were analysed (22 of which 20 were New comers $(\mathrm{NC})$ from Denmark, $36(30=\mathrm{NC})$ from Germany, $51(46=\mathrm{NC})$ from Lithuania, $71(62=\mathrm{NC})$ from Poland, $38(26=\mathrm{NC})$ from Sweden and two unidentified both of which were NC)

The second step was followed by deeper interviews with selected potential beneficiaries in each country. The interviews were conducted both through face-to-face meetings and over the phone. The analysis was made, taking into consideration all aspects of the cross border projects' development and implementation. In total 56 interviews were conducted 10 in Denmark, 10 in Germany, 16 in Lithuania, 10 in Poland and 10 in Sweden.

In the questionnaire issues related to the thematic areas as well as the greatest barriers were being investigated for potential beneficiaries especially newcomers. The general applicants including those with more experience and knowledge of the programme are also asked. The questionnaire was structured into four main parts. The first one was about the thematic areas that the potential beneficiaries are interested in. The second part examined the familiar of the SB program in the regions. The third and four parts focused on the barriers that people encounter when they apply and implement projects and what support they need.

\section{The obstacles for participating in the SBP}

It is of great importance for the Capacity Building Project to have identified the barriers for participation within the South Baltic Programme. In order for the project to help newcomers overcome their main obstacles the input from this part of the analysis has been very valuable and useful when developing the training materials.

The question posed in the questionnaire: "What do you perceive as the main obstacles for participation in international projects (You may select several obstacles, please prioritize them by selecting a number from $1-5$, where 5 means the biggest obstacle)"

The barriers for participation within the South Baltic programme differ between the countries. The below statistics will provide an overview of the most important issues in each country: Denmark, Germany, Lithuania, Poland and Sweden. 


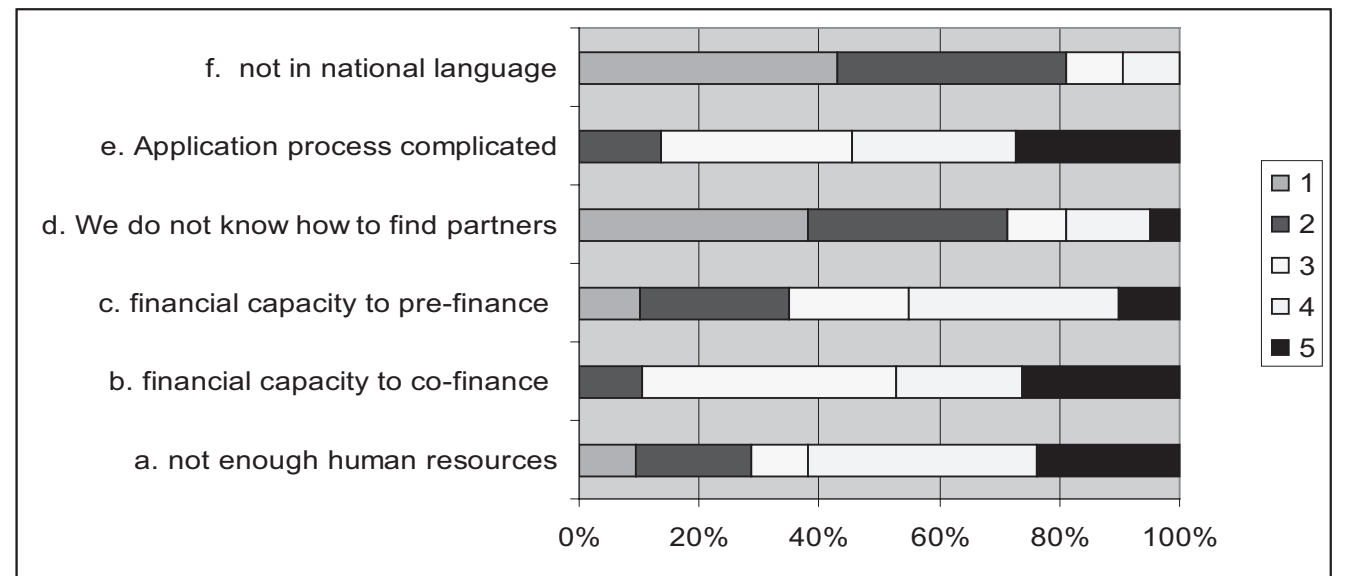

Figure 1. Denmark: Main obstacles for participation in projects identified by Danish beneficiaries

Source: Analysis of Barriers for Project Development, 2011

For the Danish respondents the English language (as official programme language) does not discourage potential participants from taking part of the programme to a significant extent. The main barriers rather consist of the lack of human resources, the financial capacity to pre-finance and co-finance and the difficulties of the application process.

Three obstacles stood out among the Danish interviewees: Finding partners overseas, the financial issue (the uncertainty of getting money back but also the need of having a great liquidity to begin with) and the lack of time and capacity. It was also considered hard and complicated to apply for EU-funding both due to the complexity, hard conditions and lack of knowledge of the programme but also because of national laws. Accounting was also considered to be an obstacle.

Most of the Danish interviewees considered it to be possible to overcome some of the barriers themselves through capacity building and by using the right people within the organization and finding the right partners to fill the gaps. Regarding the co-financing it was argued that this is mostly a problem for smaller organizations and they won't be able to conquer this obstacle themselves.

Most of the Danish Interviewees welcomed external assistance only one claimed that assistance wasn't needed to overcome the barriers (the barriers mentioned by this person was finding partners and liquidity). The desired support was mainly guidance in general (dialogue with authorities, the JTS or help from "rentan-expert" which "sounded very good" and was a "good idea") and help with the budget.

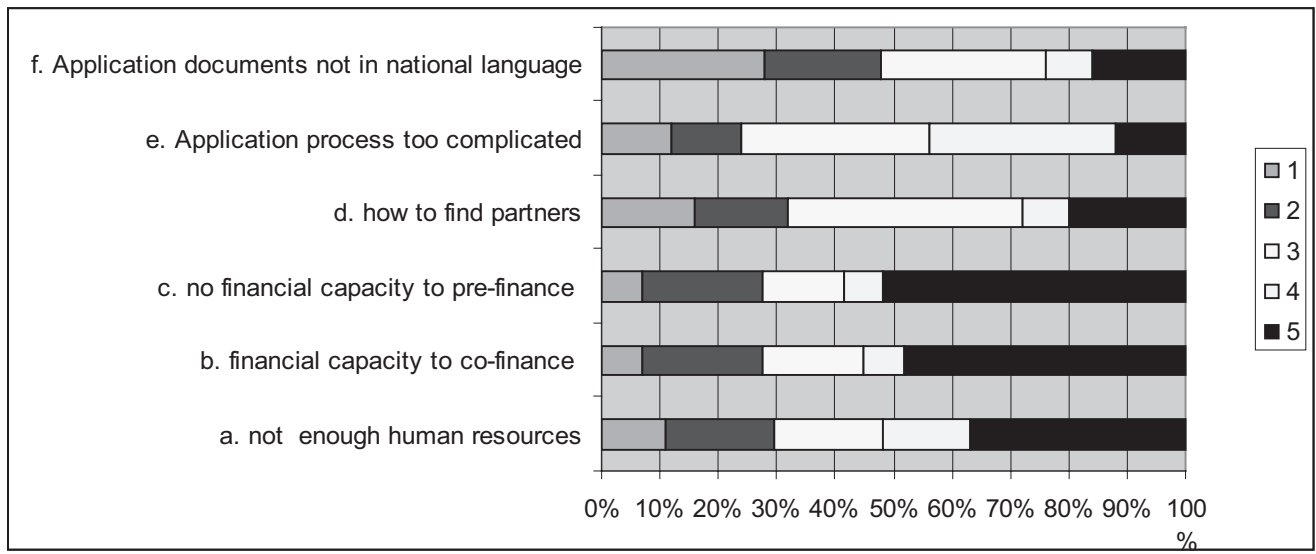

Figure 2. Germany: Main obstacles for participation in projects identified by German beneficiaries

Source: Analysis of Barriers for Project Development, 2011 
In Germany three obstacles stood out as very problematic: The financial capacity is the main problem (pre-financing and co-financing being rated as the two greatest barriers to overcome). These are closely followed by the lack of human resources which more than $30 \%$ of the respondents considered to be of very high importance. The application process and how to find partners were considered as barriers but to a significantly less extent. The smallest barrier to overcome for the German respondents was that the application documents are not translated into the national language.

Two out of 10 German interviewees not commented on the main obstacles. The most obstacles were to acquire money for pre-finance, co-finance and lack of support from regional decision-makers. The barriers mentioned were: language difficulties, no transparent work of administration, dread of competition, third party founds hardly expected, finding partner, cooperation partner structure, contacts, guidelines, competences and resources in term of time and personnel. Most of the German interviewees claimed that the language obstacles could be overcome by themselves for example through dialogue. However most of them stated that they would also need assistance from regional decision-makers, partners.

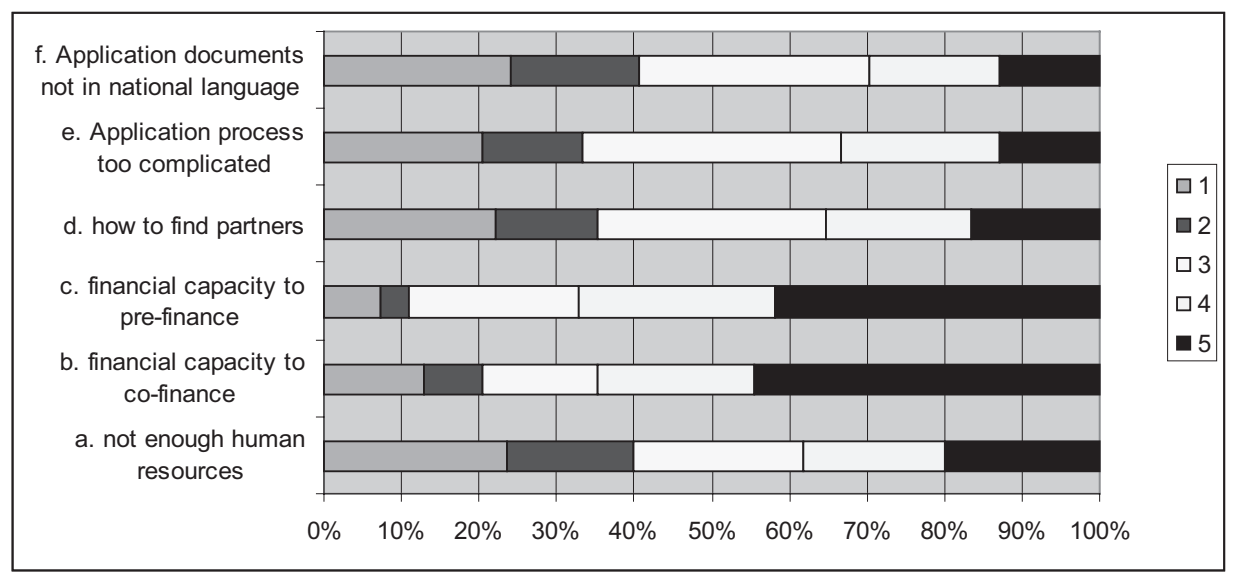

Figure 3. Lithuania: Main obstacles for participation in projects identified by Lithuanian beneficiaries

Source: Analysis of Barriers for Project Development, 2011

The greatest obstacles for the Lithuanian respondents were financial capacity to pre-finance and financial capacity to co-finance. The rest of the barriers mentioned were considered less important and were almost equally ranked.

About one third of the interviewed did not know which the main obstacles could be or chose not to answer the question. Of those who answered the main issue was co-financing followed by workload and lack of information. Other reasons mentioned were negative institutions, lack of partners, short time to prepare, lack of experience, unclear forms and a different culture of communication.

The answers to whether these barriers could be overcome by the organizations themselves were quite varying. While a few considered it to be possible by strengthening the English skills for example some said it might be possible but very difficult and others considered it to be out of their power. Regarding assistance to overcome the barriers it was agreed by all who answered that question that external support was important. None of the Lithuanian interviewees had considered applying for the SBP but later refrained from it. 


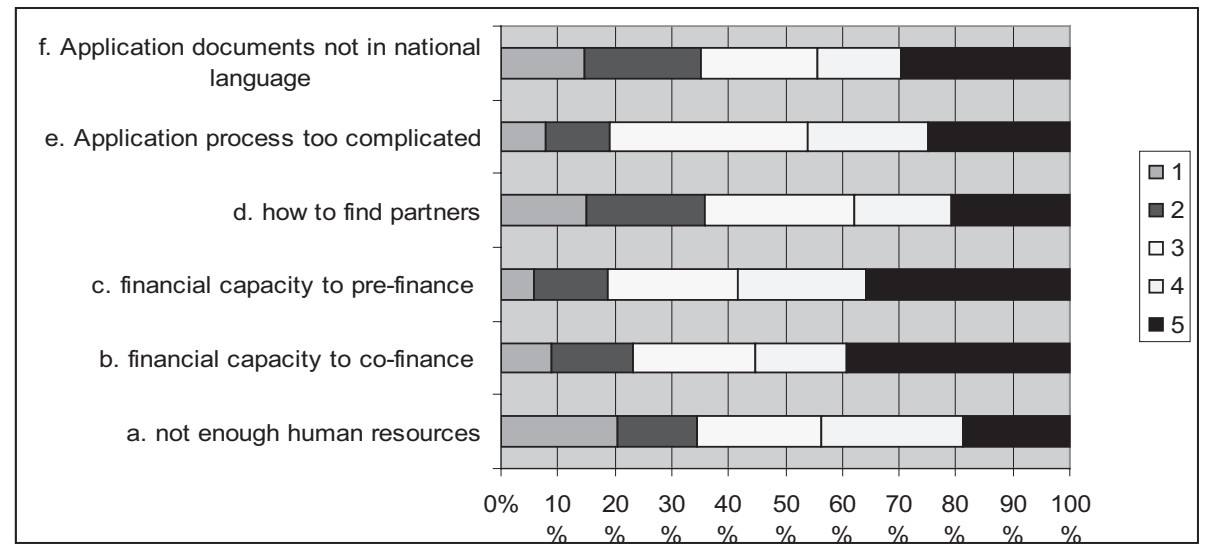

Figure 4. Poland: Main obstacles for participation in projects identified by Polish beneficiaries

Source: Analysis of Barriers for Project Development, 2011

Once again the financial aspects (pre-financing and co-financing) were identified as the biggest obstacles, but in relation to the other countries none of the barriers stood out to the same extent in Poland. All were considered to be of relatively high importance.

Few of the Polish interviewees had refrained from applying for funding with in the South Baltic Programme. For those who had the main reason seemed to be lack of partners or other problems which were not related to the programme itself.

They perceived the main obstacles to be staff shortages, trouble finding partners and the language barrier. It was also evident that the focus had been on other projects (mostly infrastructure) where funds were tied up which had led to a lack of funds. It was evident that the obstacles were not considered possible to overcome without external assistance, but it wasn't clear who should be responsible, and of what. Consultancy companies, institutions and advisory bodies were suggested to mediate contacts, and give support in the creation and implementation of the project. Although most of the interviewees could not point at any specific barriers during the application process a few were mentioned; language barriers, communication barriers (no cooperation with partners from abroad) and trouble formulating the application.

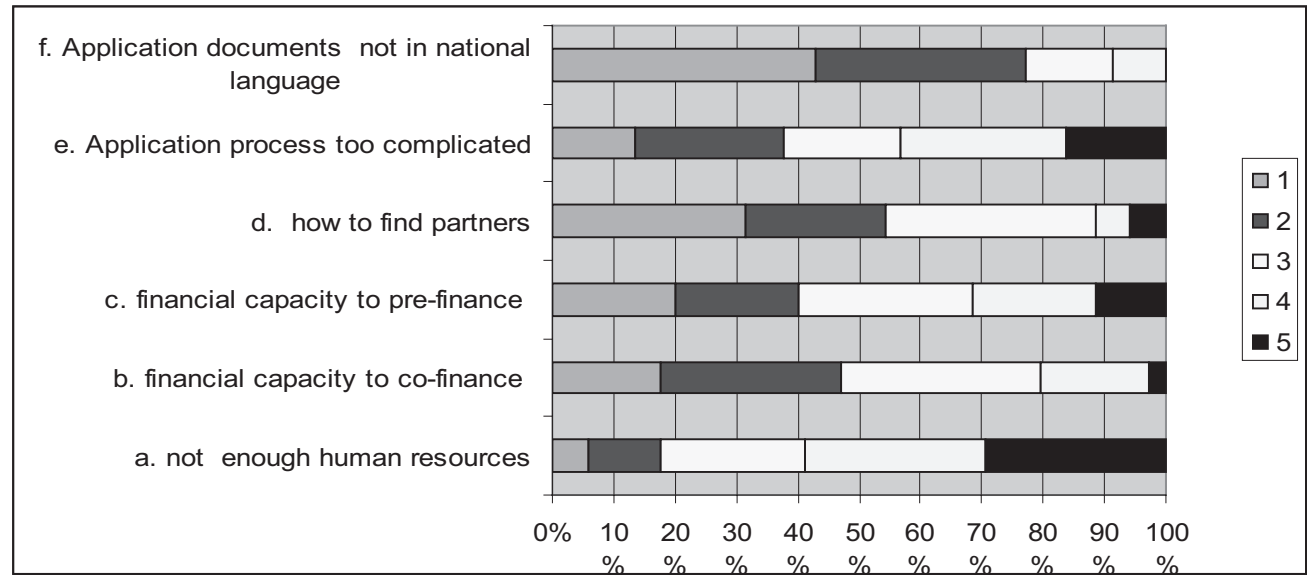

Figure 5. Sweden: Main obstacles for participation in international projects identified by Swedish beneficiaries Source: Analysis of Barriers for Project Development, 2011

Similar to the situation in Denmark the usage of English is not considered to be an important barrier and neither is finding partners. The main obstacle for the Swedish respondents is the lack of human resources. 
Overall, lack of time seemed to be the key-problem. Whether it is needed to familiarize oneself with the programme, to find partners or to write an application the interviewee's organizations simply didn't have the time or were resistant to take the risk of investing large amounts of time into a project. Language- and cultural differences were also problems as well as difficulties in writing an application and meeting the high demands of the programme. It was believed that there is a mental barrier when it comes to international programmes (due to ignorance and lack of experience) which could be bridged by providing information and marketing the benefits of international projects and by educating potential beneficiaries in understanding the rules and regulations and adjusting an application to these. The Capacity Building initiative is much welcomed, but those familiar with the South Baltic Programme also point out that the contact points have been very supportive and helpful in the past. Most agreed that external support is needed to overcome the main barriers. Some of the interviewees were specific with what support they desired. The suggestions ranged from help to focus the project and help with writing an application to getting help with leading the project and reimbursements for translators (since they quickly eat up the budget). There was also a request to target information so that when a measure related to certain issues comes up information regarding this would be directed to those concerned, they argued that there is limited time to cover what's happening and relevant information often drowns among the massive amounts of information they receive. However no one had a clear idea of who should provide these services and whom should be responsible. Suggestions ranged from the contact points, the JTS, and the Capacity building projects to the county councils or special consultants.

Another barrier mentioned was that it is hard to find partners and once you have it's hard to get them together to talk the project over thoroughly. Money for pre-meetings is needed.

In more than one case the SBP had been considered but didn't seem to be the most strategic choice when applying for funds. Regional funds often seemed to be a wiser choice for many reasons: No language- and cultural barriers. The international dimension sometimes demanded that the project became bigger than necessary. Others had decided not to apply in the SBP because their partners had found the programme timeconsuming and the application process difficult in the past.

\section{The most useful supports}

Out of the 220 questionnaires reviewed 199 would be more interested in applying for funds from the SBP if they got support. Below the answers are first specified by country and finally what the newcomers have identified as the most useful support. The question posed in the questionnaire: "which type of support is the most useful for your organization in order to apply to South Baltic Programme?"

In Denmark the greatest needed for support seems to be during the budget preparations. Information on the application procedure is another issue where the need of assistance is evident. The third most important area for support is getting help to find relevant partners followed by "description of activities". The two remaining issues (developing a complete application and tailoring a project idea) do not need as much support. This is particularly true for tailoring the project idea which was only identified as a barrier by approximately $10 \%$ of the Danish respondents.

Nothing stood out when the Danish interviewees considered which type of support would be most useful for their organization in order to apply to the south Baltic Programme. Three people mentioned Finding Partners and two rent-an-expert. The rest of the suggestions were only mentioned by one person: Developing a project idea; formulating the project idea; Dialogue with JTS and CP's; Time management; Matching the programme; Budget and Technical information. The support was mainly needed in the beginning while addressing the above issues, finding partners, developing the project idea etc. Few of the interviewees could consider paying for support, among those who couldn't one stated that he would if there was a guarantee that the application would be approved. During the application process the main barrier seemed to be related to partners. Mentioned problems were; finding them in the first place, getting everyone together, the wishes and needs of many organizations, communication with partners and getting the process to flow and partners who quit the last minute. Other obstacles mentioned were formulating the application, waiting for a long time 
without getting any response and not being able to do anything in the meantime. A few people didn't have any experience and chose not to comment although one pointed out that it looked extensive and bureaucratic. Almost none of the Danish interviewees had received support previously. Those who had experienced it had done so through partners, programme administration, volunteers and internal capacities.

In Germany once again budget preparations are in greatest need of support. Developing a complete application, tailoring a project idea and describing the activities are also important. The development of a complete application is higher ranked in Germany than in other countries. From the analysis we can also draw the conclusion that all areas of support are generally of high importance.

The most useful support for the interviewees organizations were conditions for entrance, search for partners and help with the application process, budget planning, accounting and reporting, hence most support was needed in the beginning. Only two out of 10 interviewees would not be willing to pay for support although one of them came with the reservation of it depending on the financial situation.

The mentioned bottlenecks during the application procedure were guarantee of partners and red tape (excessive regulations). Most of them had received external support previously (one mentioned that it was through external agencies, one mentioned from ViaBalticaNordica, BSR Innoreg, BalticBiogas) in the areas of funding, content and the application process. Both perceived it as a positive experience such as pleasant, good advice and very helpful. In general they felt that they had received good assistance.

In Lithuania the help with the budget preparations are again the most useful support. The other predefined barriers all seem to be in need of assistance and are of almost equal importance. Generally all areas are of importance for the Lithuanian respondents.

Mostly the Lithuanian interviewees desired advice and consultations in general. The areas specifically mentioned were formulating and framing the idea, financial matters, preparing proposals and drafting trainings. Help with translations was another suggestion.

Most of the interviewees wished for quite extensive support throughout the application process. It is possibly because of their lack of knowledge about the programme. The people who had been specific all agreed that the support beginning was the most important reasons mentioned were that they needed help to formulate a clear idea to begin with since the rest is based on this. They also mention that having trainings in preparations of the application would be useful. However, only two have stated that they are willing to pay for such support.

Only three people reported that they considered there to be bottlenecks during the application process. These mentioned the language barrier and the lack of knowledge and partners.

In Poland the main field of support identified by the polish respondents is "Providing information on application procedure". Similarly to the other countries the budget preparation is mentioned as one of the greatest barriers to overcome. But all areas pre-defined were acknowledged as important.

There was a desire from the interviewees to receive consultations throughout the process of creating and implementing the project, especially in the beginning with the writing and help in finding information on the application procedure. Many also wished for help in finding partners. Although the support was much desired only two out of the ten would be willing to pay for assistance. All of the polish interviewees had experience of support from previous projects and had perceived it "as expected".

In Sweden the support in budget preparations was highly prioritized by the Swedish respondents. The second highest priority was help in finding partners and providing information on the application procedure. Developing a complete application was ranked as the biggest obstacle when taking only the highest scores into account, but when taking the second highest scores into account it loses its importance slightly.

To have someone review/examine the application and make sure you have framed the project in accordance with the Programme measures and used clear wording etc. was mentioned more than once, as was budgeting. Help with the application and how to structure and facilitate results was also mentioned. Educations also came up. A project school about intercultural communication was suggested and also an inspirational day with information and education to show the benefits of cross-border cooperation. Guidance was considered necessary to overcome the mental barriers. 
Most interviewees would like to receive support in the beginning and the only processes mentioned specifically were writing the application including a budget and the process from generating the idea to writing the application.

The interviewees would generally be willing to pay for support if the benefits exceeded the costs, but they were clear about this matter being a question for the management to prioritize.

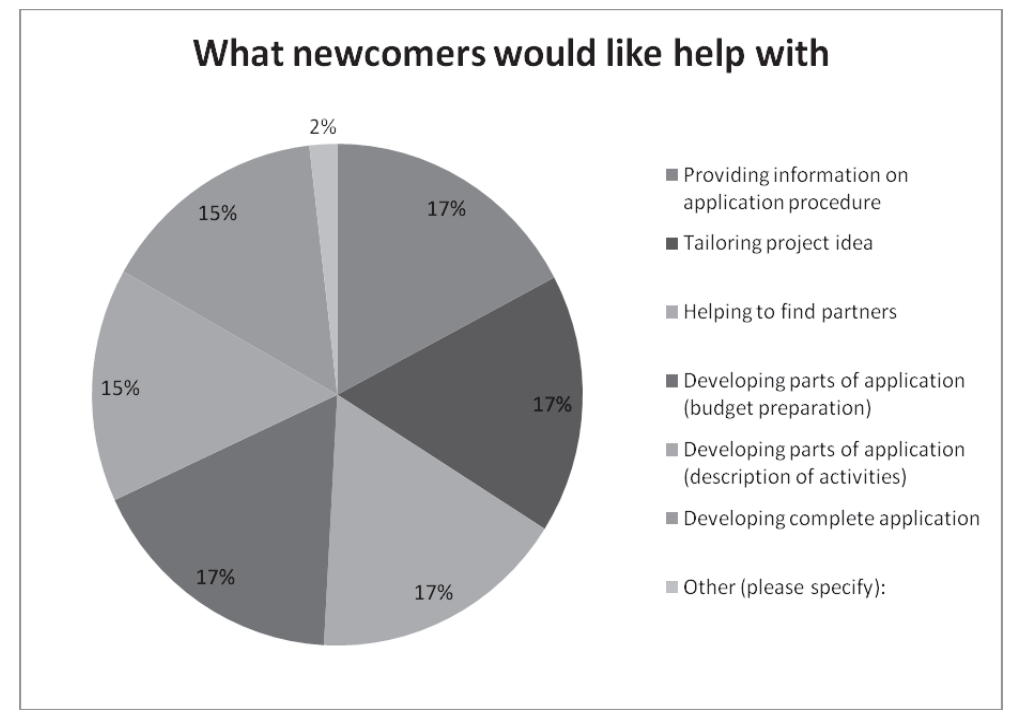

Figure 6. Needs for support in project development indicated by newcomers

Source: Analysis of Barriers for Project Development, 2011

In Denmark "Providing information on application procedure" and "Developing parts of application (budget preparation)" stood out.

In Germany "Tailoring project idea" had the highest score

In Lithuania "Developing parts of application (budget preparation)", "Helping to find partners" and "Tailoring project idea" had almost the same high score.

In Poland "Providing information on application procedure" got a higher score than the other options.

In Sweden "Developing parts of application (budget preparation)" got the highest score closely followed by "Helping to find partners" and "Developing complete application"

Here are a few examples of other suggestions of support mentioned: accounting - follow-up; project management; financial support; translation into English.

\section{Quality analysis of CBP services}

Quality analysis was based on feedback and opinions received from project beneficiaries, external experts and CBP team. In order to get a broad picture of all services our project offered, 4 questionnaires were developed:

1. Post-training questionnaire - distributed among national trainings participants;

2. Post-workshop questionnaire - distributed among the participants of cross-border workshops;

3. Rent-an-Expert evaluation questionnaire for experts and mentors;

4. Rent-an-Expert evaluation questionnaire for beneficiaries - distributed among Lead Beneficiaries of projects who received expert/mentoring support.

The aim of the training (a) and workshop (b) questionnaires was to determine whether these events proved useful for the beneficiaries. They focused on the concept and structure of these events, usefulness 
of presented material and topics covered. Beneficiaries were also encouraged to share their suggestions for possible improvements and any other observations they might have.

Rent-an-Expert (c) and Mentoring (d) questionnaires were structured into two main parts. The first one focused on the cooperation between the beneficiary and expert/mentor. The second part examined the procedures of Rent-an-Expert service and the quality of CBP support in the arrangement of experts/mentors' help.

In total 243 questionnaires were analyzed: 139 post-training questionnaires, 64 workshop questionnaires, 19 questionnaires from Rent-an-Expert users and 21 questionnaires from experts and mentors. The results were similar in all countries covered by the analysis that is why no country division is used in presenting the results. However, if any serious discrepancies were revealed in any of the examined aspects, this is taken into account and presented accordingly.

The CBP supported its beneficiaries through three types of activities: national trainings, cross-border workshops and Rent-an-Expert facility. All these services were designed based on the beneficiaries' needs identified in the Analysis of Barriers.

\section{Conclusions}

1. The interviews mirror the questionnaires quite well when it comes to the thematic areas if the different measures. The deviations are explained by the relatively small number of people interviewed in comparison with the number of people who filled out the questionnaire.

2. After analysing the interviews the conclusion follows that the answers to most of the issues touched upon in the questionnaire and during the interviews are evident for most EU-funded programmes and not only the South Baltic Programme.

3. After analysing both the questionnaires and interviews it was evident that there was a contradiction regarding the English language as a barrier in the application process. While the questionnaires showed that this was not really a problem the interviewees on the other hand identified this barrier as an important one. This contradiction could be explained by the lack of language skills among the human resources. Even though there is enough staff in a company there is still a lack of human resources if they do not have the relevant skills. The lack of human resources was a far bigger issue in the questionnaire than the English language but the two might be related which would explain the deviations between questionnaire and interview results. While the questionnaire points out lack of human resources the interviewees state the English language to be a barrier as well. The reason might be that the human resources don't have relevant skills, such as English.

4. In the interviews those who couldn't point out any specific barriers where in many cases the same people who had no experience in the application process.

5. All areas of support are generally important in the South Baltic Programme. Since it is assumed there is a need for long-term support to build up capacity.

\section{References}

About Capacity Building project. (2010). Website: http://www.sbpcapacity.org/info/about

Analysis of Barriers for Project Development. (2011). Website: http://www.sbpcapacity.org/documents /pdf/Analysis_report.pdf

Capacity Newsletters Nb. 1, 2 and 3. (2010-2011). Website: http://www.sbpcapacity.org/info/temp

Communication from the Commission to the European Parliament, the council, the European Economic and Social Committee and the Committee of the Regions concerning the European Union Strategy for the Baltic Sea region Action Plan. (2009). European Commission. Brussels, SEC (2009) 712/2.

EU Strategy for the Baltic Sea Region. (2010). Website: http://en.southbaltic.eu/index/?id= 18997733 ec258 a9fcaf239cc55d53363

Galimi paramos gavejai ir partneriai. (2010). Website: http://www.pietubaltija.lt/index.php/programa/galimi- paramos -gavejai- partneriai. html

Management extra. Project management. (2007) Elsevier. 
Orr, A. D. (2007). Advanced project management: a complete guide to the key processes, models and techniques. London and Philadelphia: Kogan page.

Self-evaluation report of the Capacity Building Project. (2011).

South Baltic Cross-border co-operation programme 2007-2013. Operational programme approved by the European Commission on 20th December. (2007). Website: http://en.southbaltic.eu/files/ ?id_plik =176

South Baltic Cross-border Co-operation Programme 2007-2013, Programme Manual, 8th Call for Proposals. (2007). Website: http://en.southbaltic.eu/files/?id_plik=3079.

South Baltic publications. (2011). Website: http://en.southbaltic.eu/files/?id_plik=1517

Young, T. L. (2006). Successful project management. 2 edition. London and Philadelphia: Kogan page.

\title{
TARPTAUTINIO BENDRADARBIAVIMO PRAKTIKA GEBEJIMU UGDYMO PROJEKTO ATVEJU: ILGALAIKËS PLETROS UŽT I K R I N I M A S
}

\author{
Rasa Viederyté, GiedrĖ StrakšIENĖ \\ Klaipèdos universitetas (Lietuva)
}

\section{Santrauka}

Straipsnyje analizuojama Pietų Baltijos regiono strategija Europos kontekste, apžvelgiama Pietų Baltijos programa, skirta spartinti šio regiono plètra, didinant jo konkurencingumą ir žmonių bei institucijų integracija.

Atsižvelgiant ị Pietų Baltijos programos prioritetus, joje gali dalyvauti projektai, kuriais skatinamas ekonominis konkurencingumas: verslumo plètra, aukštojo mokslo ir darbo rinkos integracija ir transporto prieinamumas, bei nagrinèjamos Baltijos jūros aplinkos valdymo, energijos taupymo, atsinaujinančios energetikos, gamtinio ir kultūrinio paveldo naudojimo regioninei plètrai temos, igyvendinamos vietos bendruomenių iniciatyvos. Siekiant ugdyti pareiškèjų gebejjimus, PB programos dalimi tapo projektas „Gebejjimų ugdymas“. Šio projekto (CAPACITY) tikslas - padèti potencialiems paramos gavėjams (ypač naujokams iš regioninių savivaldybių ir NVO) plètoti labiau susijusias su realiu igyvendinimu ir geriau parengtas projektų paraiškas.

Straipsnio tikslas - gebėjimų ugdymo projekto pavyzdžiu akcentuoti tvarų vystymąsi tarpvalstybinio bendradarbiavimo praktikos kontekste.

Tyrimo uždaviniai: teoriškai pagrịsti Pietų Baltijos programos „Gebejjimų ugdymas“ projekto koncepciją, atlikti empirinę dalyvavimo projektuose barjerų ir paramos analizę ir palyginti skirtingų šalių atsakymų rezultatus.

Taikyti šie darbo metodai: mokslinès literatūros ir dokumentų analizè, klausimynas ir interviu raštu, statistinè duomenų analizè.

Igyvendinant „Gebėjimų ugdymo“ projektą buvo organizuojami mokymai pareiškèjams nacionalinėmis kalbomis, tarptautiniai mokymai, sudaryta galimybė nemokamai gauti ekspertą konsultuotis dẻl projekto paraiškos rengimo. Iš viso apmokyta apie 270 asmenų visame regione, iš jų: 88 - Švedijoje, 66 - Lenkijoje, 43 - Lietuvoje, 42 - Danijoje ir 28 - Vokietijoje. Tikimasi, kad igyti pagrindiniai gebejjimai, kaip rengti projektą, leis plètoti naujas projektų idèjas ir teikti paraiškas ateityje, paskelbus naujus kvietimus.

„Gebejjimų ugdymo“ projekto partneriai, padedant Regionų kontaktiniams atstovams, savo šalyse surengè praktinius mokymus potencialiems Pietų Baltijos programos projektų pareiškèjams. Net 15 mokymo sesijų suorganizuota įvairiose Pietų Baltijos programos šalyse: 3 Lietuvoje (Kretingoje, Tauragèje ir Klaipėdoje); 3 Danijoje (2 Zealand ir 1 Ronne); 3 Vokietijoje (Rostock); 4 Švedijoje (Kalmar, Blekinge, Skane ir Kronoberge). Mokymų sesijų dalyviai susirinko iš regioninių apskričių, nevyriausybinių organizaciju, 
muziejų, universitetu ir kitų organizacijų. Jiems vadovavo „Capacity Building“ projekto partneriai. Mokymai skirti tarptautinių projektų plètrai, akcentuojant pagrindines Pietų Baltijos programos idèjas. Užsièmimų metu taikyti aktyvaus mokymosi (angl. Action Learning) metodai, t. y. dalyviai mokèsi analizuodami konkrečius studijų atvejus ir praktinius pavyzdžius, kurie leido jiems suprasti ir numatyti projekto pletros procesą. Mokymų konsultantai/ekspertai lavino pagrindinius dalyvių gebejjimus, kaip plètoti ir rengti projekta, pavyzdžiui, tokius kaip struktūros kūrimas, veiklos planavimas, pagrindinių žinių apie projektą teikimas ir pan. Kad mokymų metu būtų veiksmingai perteikta informacija, $2010 \mathrm{~m}$. rugsèji išleistas naujas leidinys (mokymo medžiaga), kaip plètoti projekto idejją parengti projekto paraiškos veiklų bei biudžetines dalis, kaip susirasti partnerių ir pan.

Siekiant sukurti efektyvias priemones ir metodus, vykdytas empirinis tyrimas (interviu ir klausimynas), kurio tikslas - išsiaiškinti, kas trukdo plètoti projektus, kokios pagalbos pageidautu pareiškèjai.

Pagrindiniai projektų plètros barjerai yra šie: nepakankamas anglų kalbos mokejjimo lygis, nepakankami organizacijų žmogiškieji ištekliai, problemos dẻl avanso teikimo ir kofinansavimo, bendrosios informacijos apie Pietų Baltijos programą, partnerių stoka ir kt.

Pagrindinès pageidaujamos pagalbos sritys: projekto idejos generavimas, projekto biudžeto sudarymas, partneriu paieška, bendravimo tarp skirtingu šaliu partneriu palaikymas ir puoselejjimas, informacija apie paraiškų pateikimo ir vertinimo procesus.

PAGRINDINIAI ŽODŽIAI: tarptautinis bendradarbiavimas, gebejjimų ugdymo projektas, Pietų Baltijos programa.

JEL KODAI: O19, O22, O31, O57. 